\title{
Bell Daniel A., Beyond Liberal Democracy, Political Thinking for an East Asian Context
}

Princeton, Princeton University Press, 2006, 379 pp.

\section{Sébastien Billioud}

\section{OpenEdition}

\section{Journals}

Electronic version

URL: http://journals.openedition.org/chinaperspectives/3183

DOI: $10.4000 /$ chinaperspectives.3183

ISSN: 1996-4617

\section{Publisher}

Centre d'étude français sur la Chine contemporaine

Printed version

Date of publication: 1 November 2006

Number of pages: 73-75

ISSN: 2070-3449

\section{Electronic reference}

Sébastien Billioud, «Bell Daniel A., Beyond Liberal Democracy, Political Thinking for an East Asian Context », China Perspectives [Online], 68 | november- december 2006, Online since 06 January 2009,

connection on 21 September 2020. URL : http://journals.openedition.org/chinaperspectives/3183

DOI : https://doi.org/10.4000/chinaperspectives.3183

This text was automatically generated on 21 September 2020.

(c) All rights reserved 


\section{Bell Daniel A., Beyond Liberal Democracy, Political Thinking for an} East Asian Context

Princeton, Princeton University Press, 2006, 379 pp.

\section{Sébastien Billioud}

\section{EDITOR'S NOTE}

Translated by Peter Brown

1 This work by Daniel A. Bell can be seen as a provocative attempt to show that there are morally legitimate alternatives in East Asia to a Western-style liberal democracy. In the writer's view, it is vital to take the local cultural context into account if one is to think of spreading human rights, democracy and capitalism.

Daniel A. Bell is a Canadian citizen who is Professor at Qinghua University in Beijing. His work lies in communitarianism, one of the more fruitful areas of contemporary American philosophy, which came into being in the late 1970s as a reaction to the "liberal" philosophy of John Rawls. Bell has, with others, contributed to getting firstrate philosophers such as Charles Taylor and Michael Walzer, who came out of this movement, interested in the Chinese intellectual tradition.

Methodologically, Bell's position is at the junction of theory and practice. For him, thinking the political also means thinking of its concrete applications. His approach is resolutely inter-disciplinary, with input from philosophy, political science and even sociology.

4 Beyond Liberal Democracy is composed of 12 chapters [FE published as articles医, a bibliography and an index. Following an introductory chapter, the book is divided into three parts, which deal, in order, with human rights (chapters 2 to 4), democracy (chapters 5 to 8), and capitalism (chapters 9 to 11). A final, original 
chapter aims to clear up a certain number of misunderstandings, which Bell claims are due to inadequate responses he had given at various lectures.

In the first of the three chapters devoted to human rights, Bell uses Mencius to think about what can constitute a just war. The Chinese thinker's "theory" would allow war to be justified, quite possibly more than would the humanitarian right of interference, when a civilian population is deprived of the means of subsistence. Conversely, it would also undermine the bases of any justification of war for communitarian reasons (in the name of recovering ancestral lands, or of a linguistic or racial community, etc.).

Bell then gives an overview of a certain number of debates that have taken place on human rights and values in Asia: (a) the debate over the possibility or otherwise of assigning a priority to certain rights; (b) the debate over the foundation of human rights and the taking into account of local values; (c) the question of "moral pluralism" and the possibility of reducing or extending human rights in Asia; (d) the question of the interest of intercultural dialogue over human rights.

Chapter 4 draws especially from the practical experience of NGOs working in the field of human rights. Bell examines four "ethical challenges" facing them: the conflict between human rights and local cultures; the issue of economic, social and cultural rights; the compromise required when working with authoritarian regimes; the risks of the loss of independence associated with fund raising campaigns. In the writer's view, given that any strategy comes at a cost, it is the context, more than grand principles, which must finally determine the approach to be adopted. In extreme cases of conflict between "Western inspired norms of human rights" and local cultural rules, he tends to privilege the latter, at least where they are derived from values worthy of respect.

Chapters 5 to 8 are concerned with the question of democracy. A study devoted to physical education in antiquity enables the author to put forward the view that its promotion in Greece gave birth to a conception of "active citizenship", which remains unimaginable in Confucian societies: it would come up, on the one hand, against a tradition that has always valued the family more highly than the polis and, on the other, against an elitist conception of the political.

Inspired by the thought of Huang Zongxi, Bell tackles the question of elitism in the following chapter, which he relates to the possibility of a Confucian-inspired democracy. A democratically controlled meritocracy, which had in former times been institutionalised through the examination system, would still today be a solution to the management of complex societies. In a two-chamber system, the upper chamber could become a Xianshiyuan, an assembly of scholars recruited by competitive exam who would be more capable of maintaining some critical distance than their peers in the lower house.

10 In Chapter 7, Bell takes as his starting point the experience of several Asian countries to explain that democracy can, in some cases, put ethno-cultural minorities at risk, particularly as programmes of nation-building are often centred on the majority culture. In his view, the promotion of democracy must therefore be accompanied by an assessment of the risks that it is likely to carry both in terms of social cohesion and peace.

11 The final chapter in this second part consists of the author's thoughts on an experience in teaching political theory in Singapore. This has two superimposed elements: one is a reflection on the extent to which cultural differences are taken into account in the 
classroom; the other, to which Bell devotes less attention, involves considerations on the finality of the educational process in the development of citizens.

The final part poses the question of the validity of the liberal capitalist model in East Asia. First, Bell deals with the influence of Confucianism on the distribution of wealth. Taking his cue from texts by Confucius and Mencius, he makes the point that the major issue for any good government is how to resolve, first and foremost, questions of a material kind. There are two corollaries to this, involving, on the one hand, restrictions on property rights, and, on the other, even today, a particular conception of this right, which, focusing more on the family than on the individual, would tend to protect those who are weaker.

Bell then tries to identify a type of East Asian capitalism that is adapted to the current period of globalisation, that is, one which is characterised both by its efficiency and by its positive contribution to social and political objectives. He distinguishes it from Anglo-Saxon capitalism, as well as from the Asian model glorified prior to the crisis of the 1990s. In particular, he explores the positive aspects of strong state interventionism in terms of education and the contribution of often informal and non-state mechanisms to the politics of social protection. Lastly, he stresses that such an East Asian capitalism also strengthens the cohesion of a community and the emotional links between its members.

Finally, the writer addresses the issue of the rights of migrant workers through the example of household employees (Filipinos and Indonesians in Hong-Kong and Singapore, migrants in Chinese cities). He explains how the call for formal equality between individuals can be counter-productive and why non-liberal laws, in addition to Confucian ethics, can in the end enable very difficult situations to be managed in a way that may be more just and harmonious.

By taking an interest above all in questions of values and by proposing to think in a non-dogmatic way about their practical implications, Bell must be praised for entering into a debate which is likely to be increasingly topical and lively with the emergence of new powers like China and India. He finds a formula that very nicely encapsulates the challenge that lies ahead by evoking "the encounter between various universalisms" ( $p$. 328). Putting it like that is, in our view, both to recognise the importance of culture (for defining public policies, setting up institutions, etc.), and to refuse to engage in discourses that would essentialise it only to instrumentalise it the better. Finally, and this is an important point, it is also to note that the spread of values cannot be unidirectional and that Chinese thought today has something else to offer besides the production of ideological artefacts. The difficulties do not of course disappear merely by articulating such factors; indeed, Bell does not engage in much theoretical speculation on his conception of universalisms, as he is especially interested in the way in which those policies that take account of the cultural context are implemented. In doing so, he exposes himself to a number of objections.

No doubt anticipating the polemical debates to which his book of essays will give rise, the author is very careful to hedge his arguments with a great many provisos. He largely anticipates the objections and strives to forestall them by means of a sophisticated, measured and well-informed presentation, without being afraid on occasion to point out any weakness of argument even when it is on the same track as his own. In short, his presentation, albeit normative, is in no way dogmatic, and his propositions, whether one accepts them or not, are a stimulating impetus to discussion. 
Another of the book's strengths lies in the multitude of concrete examples and scenarios that serve to illustrate its more theoretical propositions. Bell often has recourse to humour, sometimes to good avail, as he peppers his work with lively personal anecdotes drawn from many years of living in an Asian environment. He also calls on his lived experience to make many fruitful comparisons between different countries in the region.

Notwithstanding all these elements, a certain number of questions do arise in the reader's mind. An initial observation that one can make has to do with the areas of Chinese thought dealt with by Bell, foremost amongst which is Confucianism, and to a lesser extent Legalism. The Confucian sources to which he refers are in the main the great classics (Confucius, Mencius, Xunxi) plus a few other personalities like Huang Zongxi (1610-1695). No one would think of contesting the major importance of these figures or the inspiration that they can still offer us today. Yet, Chinese thought has been constantly reconfiguring itself over the ages. In the twentieth century, for instance, Confucianism encountered Western philosophy and this saw the emergence of first-rate figures (Xu Fuguan, Tang Junyi, Mou Zongsan, among many others). Even today, there are many intellectuals who have drawn their inspiration from Confucianism, although Bell does not deal much with them. It seems paradoxical that a work that tries to think about the present-day world does not consider all those contemporaries who have been asking very similar questions. In any case, it runs the risk of presenting the Western reader with a reductionist view of Chinese and Confucian thought. On questions like democracy, contemporary Confucian intellectuals are far from being all on the same wavelength, and it would have been worthwhile to allow the reader to understand this point fully rather than to reify the opposition between Confucianism and Western-inspired liberal democracy, as the author often does.

18 This leads us to make a second observation. In order to highlight certain key values of present-day East Asian societies, the book presents Confucianism as something very diverse. It refers at times to thinkers (most often from Antiquity), at others to political practices (for example, the recruitment by competitive exam of civil servants, which is the product of a later imperial China), and even to the "deep structures of Chinese culture" (to borrow Li Zehou's expression), that is to the crystallisation of habits handed down from the past (a sense of hierarchy, the promotion of the family, care for elders...). The use of these different dimensions can no doubt be readily justified, although a less-informed reader may feel that it is short on explanation in some respects. More problematic in our mind is the fact that there is hardly any overall integration of these dimensions in the book. Bell makes liberal use of ancient philosophical sources to think about present-day East Asian societies, but he pays scant attention to the dynamic interaction between ideas and history (social, political) in analysing what the "central values" of these contemporary societies really are.

The very issue of these so-called "central" values (p. 335) raises indeed another difficulty. Taking these values as a focal point tends to pass over the tensions at work, historically, in the political experience and the intellectual world of each of the societies observed. The risk, once again, is to reify oppositions and to make it more difficult for the author to arrive at the overall synthesis that it is his stated aim to achieve. For example, he opposes, albeit with a certain subtlety, Confucian elitism and Western-inspired democratic institutions to advocate a sort of compromise between 
the two in China (the democratic election of a lower house, the establishment of a kind of assembly of sages, recruited by competitive examination, who are capable of viewing things more dispassionately). The paradox is that, to get away from an overly Western view of democracy, he himself comes to regard democracy in a somewhat restrictive way, mainly through the prism of present-day Western institutions (and the vote). Yet this is to leave aside not only all the internal tensions in the history of democracy, but also those aspects of it that are not directly institutional. The writer, who is opposed to a dogmatic approach to democracy, runs the risk of ensnaring himself in what would merely be a displaced normative approach, substituting for a Western-ideal type of democracy another Confucian-ideal type, one valid in an "Asian context". The works of Pierre Rosanvallon, which invite us first of all to consider politics as a space of experience, have showed the contradictions to which a normative approach can lend itself. In La contre-démocratie ${ }^{1}$, (Counterdemocracy) he examines the non-institutional practices of surveillance, prevention and judgement that are increasingly innervating the democratic experience, with the consequent need for reconfiguration. Many of these practices (actions by independent authorities, mediators, rating agencies, etc.) have the precise goal of introducing some perspective or wisdom that the members of an upper chamber competitively recruited could, in Bell's view, demonstrate. Pierre Rosanvallon also says of them that they are to be found almost anywhere and at all times and that they could form the basis of a generalised comparative approach. A discussion of the validity of a Xianshiyuan could actually find its place in a consideration of representation in China, without Confucian and liberal archetypes of democracy being necessarily opposed.

Beyond Liberal Democracy, while at times problematic, is nonetheless an intellectually stimulating and interesting work, falling within the wider orbit of the circulation of ideas between China and North America.

\section{NOTES}

1. Pierre Rosanvallon, La contre-démocratie. La politique à l'âge de la défiance, Paris, Editions du Seuil, 2006. 